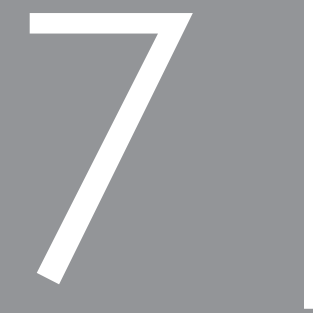

\title{
TAKING THE SCHOLARLY ROUTE IN PEER REVIEWS
}

\section{ACADEMIC DEVELOPERS AND THEIR DISCIPLINARY PEERS}

\section{Ann Cameron}

\section{INTRODUCTION}

One aspect of my work as an academic developer in the faculty of Science at a South African university has been to support teachers in the faculty by means of peer reviews of their teaching. Since I, like many academic developers, 'migrated' (Green \& Little 2013) into the role of academic developer from a teaching background, the model we use for conducting peer reviews in the faculty has evolved through experience from a 'teacher evaluation' approach to a model that emphasises support and development, and which has led to the incorporation of aspects of the Scholarship of Teaching and Learning (SoTL). In this chapter, I describe this model and how it developed. I then present research findings that demonstrate how peer reviews, as a form of in-service training, impacted on lecturers' approaches to and conceptions of teaching and learning.

To provide an appropriate background for this, I begin by describing my own 'journey of migration' into the role of an academic developer and the contexts in which peer reviews have been conducted in our faculty.

\section{FROM TEACHER TO TEACHER OF TEACHERS}

My career as an academic developer started with an invitation to move from a teaching position in earth science into an academic development post in the Science Teaching and Learning Centre (STLC) in the science faculty. This kind of journey is not unusual as many academic developers have a scholarly background in disciplines (Boughey 2013; Gosling 2009; Linder \& Felten 2015). In my teaching positions I had taught from a foundation to a master's level in a range of courses focusing either on earth science or on science education. In my new position as an academic developer, 


\section{THE SCHOLARSHIP OF TEACHING AND LEARNING IN HIGHER EDUCATION}

my work was primarily with academic staff in the ten schools within the faculty, the objective being to assist them in becoming better teachers. This largely involved conducting peer reviews for academic staff seeking promotion or tenure, as well as organising or running seminars and workshops on teaching and learning. There was no specific qualification needed for this new role, and no specific courses to be taken to prepare me for it. Like many other academic developers in South Africa, I had to draw on my own experience as a teacher, initially at a secondary school level and then in tertiary education. Within the academic development perspective, this approach to supporting and growing teaching expertise in the faculty would be viewed as a service (Gosling 2009).

In looking back on my change in role to an academic developer, I can see that I moved from a position in teaching with a well organised curriculum, a number of colleagues with similar backgrounds and interests, and a recognised qualification to do the job well, to a position with none of those characteristics. Further, in my former teaching role there was a given group of students to teach and they were there out of choice, whereas in my role as academic developer, I would have to work with 'students' who were at least my peers, most of whom were more focused on forwarding their research profiles than on learning to teach better. In my former role I could also count on some level of common knowledge among my students. However, as an academic developer, since there was at the time no teaching qualification required for university lecturers at the university, very few of the academics I met had been exposed to theories concerning teaching and student learning. For most lecturers, their teaching was the product of their own experiences and their notions of what it meant, in their discipline, to be a 'good teacher' (Frielick \& McLachlan-Smith 1999).

\section{ACADEMIC DEVELOPMENT AND THE 'PROFESSIONALISATION' OF TEACHING}

Academic development at the university has been undergoing ongoing metamorphosis during the years since South Africa achieved a democratic regime: there has been a gradual change in focus from student development through to staff development, as ideas shifted from Academic Support, where it was the students who needed to be enabled to meet the demands of tertiary education institutions, to Academic Development where the institutions themselves were recognised as needing to adapt (Boughey 2013). Today, as far as academic staff development is concerned, the buzzword is the 'professionalisation' of teaching. The anticipation is that through this process, which contains elements of development and of evaluation, the quality of teaching would improve. This would then translate into an increase in student throughput which would, in turn, be accompanied by an increase in subsidy in 
accordance with the funding profile of higher education in South Africa. As a result, the focus of the STLC was to "encourage and enhance innovative and high quality teaching and learning" (STLC Brochure 2010). The peer reviews were seen as critical to this process as it was in the work done with individual academics, situated in the individual contexts of their teaching, that the greatest shifts in practice and attitude were evident.

The move to professionalise teaching has also to be seen against the background of lecturers realising that competition in the guise of research ratings and university rankings translates into their 'job success' being closely associated with their research output. Consequently there is increasingly overt pressure on academic staff to be 'research productive'. At the same time, the broadening of access to higher education in South Africa as the country has sought to address the inequalities and injustices of the past has meant that lecturers have had to adjust to a greater diversity in the student population and to significant increases in class sizes. Further to this, the general view is that the quality of education at school level has gone down, resulting in a deepening of the 'underpreparedness' of students gaining access to tertiary education. For many lecturers who hold a traditional view of excellence in tertiary education, namely, one which is "based on the faithful reproduction of culture; (being a) master of a discipline and (developing) the general sharpening of critical faculties" (Skelton 2007:18), the confluence of demands for outstanding performance in research and teaching in an ever more demanding environment can be overwhelming and demoralising. In these conditions, clearly defined requirements regarding research output prejudice the amount of time and effort that is spent on teaching.

South African universities do not currently require certification of teachers in higher education, in contrast to the situation in, for example, Australia as described by Ginns, Kitay and Prosser (2008) and in Sweden (Lindberg-Sand \& Sonesson 2008). Courses or workshops in teaching are attended on a voluntary basis and may cover a few hours or a few days. The most intensive offering in my institution is a four-day 'Teaching Role' workshop offered by the university's central unit for the development of teaching and learning. This workshop is recommended for all new members of staff, but there is no built-in follow up in terms of changes in understanding or practice, and no formal research has been done on the impact of these courses in leading to more student focused perspectives on teaching and learning.

As far as teaching in science is concerned, many lecturers are embedded in what Frielick (2004) has described as "the positive dualisms of modernity" (p.38). They see their job as being to transmit the knowledge products of science which they have crafted into courses into students' heads, and assess whether they have absorbed 


\section{THE SCHOLARSHIP OF TEACHING AND LEARNING IN HIGHER EDUCATION}

enough to allow them to qualify. Lecturers believe that they need to be on time for lectures; occupy the 45 minutes of teaching time for each period with high quality content and then test the students to check their progress and understanding through summative tests or exams. In my experience, most have not thought about ideas of learning, or been exposed to understanding how learning takes place, or how they should be teaching and assessing to best enable student learning. They have not deeply engaged with the challenges of language or culture in teaching in multilingual and multicultural classrooms. They do not see teaching as "active recreation and (co-) construction of meaning" with their students (Frielick \& McLachlan-Smith 1999:3) because they understand that their job, as disciplinary experts, is to offer students their specialist content knowledge, and that students should play the role of recipients and take responsibility for their own learning.

Two features of the academic career structure are tenure and promotion, requiring the academic to produce a research portfolio as well as a teaching portfolio. A critical feature of the teaching portfolio is evidence of competence of practice. The university policy states that all lecturers should undergo at least one form of evaluation of at least one of the courses they teach every year (http://intranet.wits.ac.za/ Registrar's Help Desk: Policy on the evaluation of teaching).

In the policy, three different forms of evaluation are recognised: self, student and peer evaluation. However, for the purposes of promotion, evidence of all three is an advantage. Self-evaluation is often included with the statement of the lecturer's teaching philosophy, and typically includes reflections on any course developments or interventions that have been aimed at raising student performance and throughput. Student evaluation is usually in the form of centrally managed computer generated surveys. However, the option to include peer evaluations provided the opening for my particular activity, which was to engage with academics aspiring to further their career by including a peer review component in their teaching portfolios.

\section{THE TRANSFORMATIVE POTENTIAL OF PEER REVIEWS}

A 'peer' review is one typically carried out by someone of one's own standing in one's own discipline or school, but here I found several advantages to my own position as an 'outsider'. First, I was sufficiently at home in the science faculty to be considered a colleague or peer - someone with a science background and science teaching experience in the university. But in addition, I had a sufficiently distanced position from the academics in terms of their fields of specialisation to be seen as non-threatening with regard to their subject matter knowledge. However, my overriding advantage, from the point of view of being accepted as an academic 
developer, was my background and higher degrees in science education. This gave me credibility as an education specialist and in carrying out the peer reviews, I found myself serving both roles described by Bell (2001), namely, of support colleague and academic developer. Peer reviews also provided an opening to address the goals of the STLC, which included aspects related to each of the three orientations for such units suggested by Gosling (2009), namely, as having a service function; a management function; or in serving as an academic department. However, with the focus of peer reviews being on support and development, the role the STLC was most closely fulfilling in relation to peer reviews was a service function, although the reports, which were the formal conclusion to the process, also served a management function.

Research has shown varying levels of success in academic development programmes involving short courses or workshops (Boyle, While \& Boyle 2004; Sunal et al. 2010). For example, Prebble et al. (2005), in their review of the impact of academic development programmes, concluded that "short training courses are unlikely to lead to significant change in teaching situations" (p. 2). Factors that have been suggested as critical for effective academic development include the duration of engagement, opportunities for active learning, and a subject area content focus (Birman, Desimore, Porter \& Garet 2000). The study by Ginns et al. (2008:175) which indicated that a Graduate Certificate in Higher Education had been "successful in fostering the development of more complex experiences" (of teaching and learning) underscores the belief that it is long term and active engagement that is critical for successful academic development.

In contrast to short in-service courses, peer reviews are undertaken over a relatively long period of time, with a greater sense of personal investment on the part of the lecturer concerned because they feature one on one interactions and there is an expectation of response, which possibly requires changes in practice. When lecturers shift in their understanding of the purpose of teaching and start to engage with how they should teach to enable learning, they can be seen to have undergone a significant shift in their epistemology of teaching and learning. The relationship between teachers' approaches to teaching, and students' approaches to learning, has been shown in a number of studies, notably in the work of Marton and Säliö (1976). Ginns et al. (2008) confirm that research has shown that teachers who use more student-focused approaches to their teaching are more likely to foster among their students deeper approaches to learning, and that "a key outcome of intensive staff development is thus more student-centred approaches to teaching" (p. 175). 


\section{THE SCHOLARSHIP OF TEACHING AND LEARNING IN HIGHER EDUCATION}

Peer reviews offer the opportunity for staff to be exposed to a different conception of teaching and learning, which is then embedded in the context of their lived experience of teaching. Even though few people would voluntarily submit themselves to what can be viewed as a threatening process, and it is the need for tenure and promotion that usually brings them to the process, there is a change in attitude that is developing, with a growing number of lecturers seeking peer reviews simply because they are interested in developing their teaching expertise.

\section{THE PEER REVIEW PROCESS IN THE FACULTY}

Before describing the peer review process as currently conceptualised and practiced in our faculty, it should be noted that within SoTL, the notion of peer review has a more scholarly grounding in the area of teaching and learning. In that case, 'peer review' occurs in the context of the evaluation of science teachers' submissions of original research work they have undertaken in some aspects of teaching and learning. Here I present the process of peer review of teaching as we practice it, and attempt to locate it within the broader framework of SoTL and its peer review mechanism.

Peer reviews were usually initiated by an e-mail such as the following:

I believe you are the right person to approach for the purpose of doing a peer review of my teaching. I am wanting to apply for promotion and have been told that it would be to my benefit ...

In this case, the academic was actively seeking positive benefits from such an engagement. In contrast, the e-mail might read:

Professor $X$ has recommended that I should be in touch with you for some assistance with my teaching. Could you do a peer review ...

Knowing that Professor $X$ was Head of School, I found a different tone to this e-mail. Here the communication carried an alert that things were not going too well in the academics' classroom. The Head of School would have been made aware of the problem and is likely to have been asked to intervene.

A third kind of e-mail came directly from the Head of School:

Would you please contact $\operatorname{Dr} Y$ and request him to meet you for the purpose of a peer review of his teaching ...

Here the context would give a clue as to the expectations: "as he is applying for tenure ...", which would signify the expected career progression, but if it was "as he consistently gets bad evaluations from students and there is far too high a failure rate in his courses ...", it would be very clear that intervention was required, and expected. 
Each of these different types of peer review requests called for a different approach, with different expectations on both sides and different modes of interaction. In the first instance, the lecturer making the approach had a specific motive for subjecting him or herself to a scrutiny of their teaching, which was usually related to probation or an application for promotion. Here, they would approach the peer review the way an orthodontically responsible person would visit the dentist: they would be pleasant and co-operative, knowing that any 'pain' endured would be worth it in the long run. In the second case, where the engagement had been prompted by the Head of School, the lecturer was also be likely to be cooperative and willing to learn more about teaching, and to change their approach. In the third case, battle lines had already been drawn, and much skill was required for any meaningful cooperation.

Over the course of a few years, a formalised model for the peer review process evolved. This model firstly enabled the production of documentation needed for probationary or promotional purposes in affirming teaching competence; secondly, it offered the potential for development as a teacher; and, thirdly, it took into account variations of the scenarios sketched above. The model comprises an initial briefing session, where the academic is invited to meet the academic developer and where the process and purpose of the review is established. This is done by means of a 'peer review protocol' - a document that clearly outlines the process and ensures that the lecturer is aware, for example, that the academic developer may engage with students about how they are experiencing the course and the teaching. Great care is taken to put the lecturers at ease and assure them that the process is not intended as punitive, but rather that it will offer constructive feedback. Having then established dates for the classroom visits and having set time aside for the feedback discussions, it is explained that the role of the academic developer will be to observe not only what the staff member is doing as a lecturer, but that a major component of the classroom observation will be focused on watching to see what the students are doing in relation to what the lecturer is doing. Thus there is from the outset of the process the establishment of an understanding that teaching is seen as supporting learning, rather than as an activity residing in the teacher.

A variety of observation and performance lists are available which highlight criteria that can be used for the assessment of teaching. Such lists can serve to alert the lecturer to points I would be looking at during class observations, such as the quality of the classroom climate; the many issues associated with student diversity; and awareness of factors that influence student learning. A few such lists are therefore shared with the lecturers during the initial briefing meeting, to draw them into awareness of many aspects of teaching that they may not previously have considered. 


\section{THE SCHOLARSHIP OF TEACHING AND LEARNING IN HIGHER EDUCATION}

However, I prefer not to use these lists with their tick box approach which tends to emphasise judgement rather than support. My practice has been to write extensive 'field notes' during the observations, with a summary of the main points to be raised for discussion when I meet with the lecturer after class. This technique functions like a written video transcript without the 'stage fright' impact that could be associated with actually videotaping the lesson. These notes are especially useful in enabling me to give specific feedback on specific situations, and for developing an holistic picture of the teaching and learning environment over the course of the observation period.

When attending classes, I try to arrive early and select a position that will provide a good a view of the whole teaching venue. Many of the lecture theatres are tiered, and this allows me to observe student activities, including the frequency of note taking, what kind of support materials are available to students (course notes, copies of PowerPoint presentations, text books) and how students are using them. It also allows me to observe the frequency and patterns of cell phone use, which is all too common, and serves as a segue to discussions that focus on why students behave as they do. I also recommend to the lecturer that he or she should indicate to students when they first greet them that they have invited a 'visitor' to sit in on the class. That introduction serves to reduce 'suspicion' about why I am present as well as to facilitate informal interviews with students during the breaks between double periods or after class. These interactions often provide valuable insights into problems, or highlight events that may not have had specific significance for me.

The class observations are intensive and time consuming, because at least four contact sessions are prescribed in the protocol. The purpose here is to counter what may be a superficial or artificial 'glimpse' of the quality of teaching that may be afforded by only one class observation. While this takes up a lot of time, it serves to confirm or dispel impressions that may have been made in less contact time. Deeper engagement at a one on one level may be desirable, and in some cases necessary, but in the main anything more intense than the current practice, with current resources, is not possible.

During discussions after each lecture, academic staff are offered time to reflect on their view of their teaching. As a consequence, feedback often begins by looking at 'mechanical' issues such as the appropriateness of font size on their slides, the amount of information per slide, and the need to pause for students to transcribe notes before proceeding with explanations (applicable in cases where lecturers expect students to take notes in class). In some cases lecturers provide printouts of their notes, and mostly the class slides are provided on the learning management system for students to download; the possibility of using a microphone if their voice 
does not carry well; the need to moderate lighting to cater for the visibility of slides or the chalkboard (or even the lecturer); the need to increase or decrease their pace of lecturing, and so on. As the peer review progresses, lecturers become more reflective and discussion can move from the mechanical to deeper issues.

I always look for positive aspects and offer comment on the things they are doing well in order to build their confidence and confirm them in good practice. This aspect of the peer review is consonant with taking the role of 'support colleague' in Bell's model of teacher development (Bell 2001). This 'positive platform' is then used to introduce them to relevant learning theories such as sociocultural constructivism (Aikenhead 1996); the idea of situated cognition (Lave \& Wenger 1991); the notion of deep and surface approaches to learning (Marton \& Säliö 1976; Ramsden 1992); the value of constructing learning outcomes and the need for constructive alignment (Biggs 2003); the concept of pedagogic content knowledge (Shulman 1986); and the idea of the backwash effect of assessment (Biggs 2003), depending on the unique context of their teaching. They may also be introduced to the concept of different levels of thinking skills, for example using Bloom's taxonomy (Anderson \& Krathwohl 2001). The ensuing discussions create a space that is akin to switching to the role of "academic developer" in Bell's model, where educational theory is used for feedback and for developing an opportunity for reflection based on theoretical frameworks (Bell 2001).

The focus of this individual engagement is often aimed at transforming or refining what the teacher understands to be 'good teaching'. The majority of lecturers with whom I have worked define good teaching in terms of excellent preparation, and excellence in delivery of content. Getting them to define it in terms of student learning is the challenge - but it is the key to a transformed understanding of teaching, learning and assessment. Frielick (2004), who defines academic development "as a collaborative process of facilitating change in mental models of teaching and the design of educational environments to optimise the quality of student learning" (p.37), points out that to be effective and sustained, the changes that need to occur in this transformed understanding of the relationship between teaching and learning need to occur at the level of epistemology. This echoes the research claiming that a prime factor effectuating good student learning is that which understands and focuses on student learning, irrespective of the choice of teaching and learning activities and modes (Prosser \& Trigwell 2001). Bringing about such change is not always easy and peer reviews can take up to and sometimes many more than the 17 hours that we try to work within for each individual. While this may seem like a costly investment, the changes that are brought about have the potential to impact on the quality of learning for generations of students. 


\section{THE SCHOLARSHIP OF TEACHING AND LEARNING IN HIGHER EDUCATION}

\section{RESEARCHING THE TRANSFORMATIVE POTENTIAL OF PEER REVIEWS}

My introduction to the Scholarship of Teaching and Learning brought about a new way to think about the work I was undertaking as an academic developer. In the light of SoTL involving examination and interpretation of practice, my discussions and reflections with academic staff during peer reviews and then sharing with them research findings from the educational literature could be viewed as serving to develop more 'scholarly' teachers. Our engagement in the peer reviews, and the development of lecturers' teaching practice in the light of educational theory, was serving to transform teaching practice in the science faculty. As lecturers learned to reflect on what kind of teaching enables learning, they became more receptive to theoretical perspectives on learning. The translation of this learning into knowledge that started being made public through our faculty symposia, conferences, seminars and even publications, is now growing, as is interest in pursuing higher degrees in education.

As a starting point to my enquiry into the effects of peer reviews in the faculty, I was deeply influenced by the work of Frielick (2004), who emphasised that the key to sustainable change in lecturers' approaches to teaching is to bring their focus away from their own activities and onto student learning, namely, to bring about change at an epistemological level. In order for them to develop as teachers, both at an individual and at a collective level, lecturers need to develop new ways of understanding teaching and its relation to student learning. This view gave me a philosophical handle to investigate the effects of the peer reviews: I could concentrate on how lecturers spoke of their understandings of teaching, both in retrospect (i.e. prior to the peer review) and with reference to their current approaches to teaching.

I was also influenced by the work of Ginns et al. (2008) who carried out an investigation into the effects of a graduate certificate in education at the University of Sydney. That phenomenographic study, involving a small number of lecturers who had undertaken the graduate certificate in education, produced five categories of variation of teachers' experiences of teaching. Three of these categories represent teacher-focused strategies, involving shifts in understanding of the need for student engagement and learning, and two are student-focused strategies, which differ in the quality of conceptual development of the students. The structural relationship between these categories is shown in Table 7.1, which offers a matrix of strategy versus intention (Ginns et al. 2008:176-177). 
TABLE 7.1 Teaching strategy versus teaching intention

\begin{tabular}{|c|c|c|c|c|}
\hline \multirow[b]{2}{*}{ STRATEGY } & \multicolumn{4}{|c|}{ Intention } \\
\hline & $\begin{array}{l}\text { Information } \\
\text { transfer }\end{array}$ & $\begin{array}{l}\text { Concept } \\
\text { acquisition }\end{array}$ & $\begin{array}{c}\text { Conceptual } \\
\text { development }\end{array}$ & $\begin{array}{l}\text { Conceptual } \\
\text { change }\end{array}$ \\
\hline $\begin{array}{l}\text { Teacher-focused, } \\
\text { teacher-activity }\end{array}$ & A & & & \\
\hline $\begin{array}{l}\text { Teacher-focused } \\
\text { student-activity }\end{array}$ & B & C & & \\
\hline $\begin{array}{l}\text { Student-focused } \\
\text { student-activity }\end{array}$ & & & $\mathrm{D}$ & $E$ \\
\hline
\end{tabular}

Source: Ginns et al. (2008)

In this matrix:

- " $A$ " is a teacher-focused strategy aimed at transferring disciplinary information and demonstrating facts and skills of the discipline to students.

- " $B$ " is a teacher-focused but student-activity strategy aimed at transferring disciplinary information to students, but going beyond " $\mathrm{A}$ " in recognising that students need to be active learners.

- " $\mathrm{C}$ " is a teacher-focused, student-activity strategy aimed at helping students build their understanding of the discipline concepts rather than just transferring information.

- " $\mathrm{D}$ " is a student-focused, student-activity strategy aimed at helping students develop their own conceptual understanding of the discipline, rather than just helping them to acquire someone else's concepts.

- " $E$ " is a student-focused, student-activity strategy aimed at helping students develop and change their conceptual understanding of the discipline.

In spite of the different modes of academic development involved, this study gave me a framework for considering my own work at an empirical level, and I accepted the Ginns et al. (2008) offer that "these frameworks may be of use to academic developers in understanding the variability in teachers' conceptions of these concepts" (p. 184). Consequently, I sought to investigate the ways in which teachers who had taken part in the peer review process saw their teaching practice and what underpinned it, and how these ideas may have changed as a result of the peer reviews. A survey was drawn up, with the questions adapted to apply to peer reviews. This was sent to lecturers who over the period of a year had undertaken the peer review process. The questions used in my survey were: 


\section{THE SCHOLARSHIP OF TEACHING AND LEARNING IN HIGHER EDUCATION}

- Thinking back prior to the peer review, how would you describe your teaching?

- How has the peer review affected how you understand teaching, and what changes, if any, have you made in the way you teach or the way you think about teaching?

- Would you recommend to colleagues in your school to undertake a peer review? What would you give as your reasons?

- Any other comments you would like to make with regard to the peer review?

The first two questions drew on the University of Sydney study, while the next two questions were for me to gain insight into how each academic had experienced the peer review at a personal level. This was to allow me to learn about what was or was not perceived as useful or helpful, and using this, to reflect on and refine my own practice.

At a simple level, the Ginns et al. matrix highlights the difference between what is traditionally understood as distinguishing teaching from lecturing. This difference lies at the heart of the work undertaken by the academic developer during a peer review, and it is evidence of this shift in focus that was sought in my survey.

The individual survey responses, which were completed on e-mail, were then analysed in accordance with the five categories from Ginns et al. (2008). Examples of all the first four categories were found, but none from the fifth category (i.e. student-focused, with an intention to conceptual change). A few examples of these responses are given in Table 7.2, with an indication of whether they were given as a prior experience or an experience after the peer review process.

TABLE 7.2 Examples of experiences of teaching prior to and post the peer review, linked to the categories suggested by Ginns et al. (2008)

A "I enjoyed the subject matter that I was teaching and hence tried to give the students a very thorough overview of the subject, which did result in the course being very content heavy and required a rather fast delivery on my part." (prior)

"My teaching followed a sort of 'rushed' approach - I was often in a hurry to cover material in class." (prior)

B "I need to reposition my lectures relative to the students' knowledge and confidence and update my delivery to suit a changing student body." (post)

C "As a lecturer, I've always tried to take a less formal, more interactive approach; from my own experience as a student, I don't feel it's at all beneficial to stand up in front of a class and rattle off a whole lot of facts that students don't absorb." (prior)

"Getting the students to talk/discuss the answers to questions with each other (groups of $\sim 4$ ) gave students an opportunity to actively participate in the class and find out just how much they know or don't know. The responses that I received from various groups to my questions helped me gauge the understanding of a concept during the lecture." (post) 
D No quotes from lecturers are applicable from the surveys, but from class observations, three of the lecturers started bringing in activities that were student-focused, specifically aimed at helping students build their own understanding of concepts. One was teaching an honours class, the other a third-year class, both of which were small (less than 25 students) and where the lecturers felt they had more freedom in their teaching because of the level of study and the size of class.

E I did not feel I was able to categorise any lecturer at this level for the reasons outlined above. However, this is where long term formal engagement in a course such as the Graduate Certificate in Higher Education goes beyond what can be achieved in a peer review with regard to exposure to theory.

The overall findings for each category in my case study, prior and post the 'intervention' of the peer review, is given in Table 7.3. The corresponding figures from the Ginns et al. study, where the intervention was the post-graduate certificate in education, are given for comparison, in brackets.

TABLE 7.3 Analysis of academic staff experiences of teaching and learning before and after the peer review (number in brackets refers to Ginns et al. (2008) findings)

\begin{tabular}{|c|r|r|r|r|r|r|}
\multicolumn{2}{c|}{ PRIOR } & \multicolumn{5}{c|}{ POST } \\
\cline { 2 - 7 } & \multicolumn{2}{|c|}{ A } & \multicolumn{1}{|c|}{ B } & C & D & E \\
\hline A & $10(6)$ & & $3(1)$ & $6(1)$ & $1(3)$ & (1) \\
\hline B & $1(2)$ & & & $(1)$ & $1(1)$ & \\
\hline C & $1(5)$ & & & $(2)$ & $1(2)$ & $(1)$ \\
\hline D & & & & & & \\
\hline E & & & & & & \\
\hline
\end{tabular}

In assigning performance to the levels of variation, it was clear that shifts in teachers' understanding had occurred. However, I was not confident in trying to judge the level of practice in categories that referred to the kind of conceptual understanding that was happening for students as I had not engaged with the students. However, referring back to Frielick's contention that sustainable development of practice demands an epistemological change, it is possible to suggest, from the visible shifts in teaching practice, that there was the potential for conceptual change as well.

\section{DISCUSSION}

The key finding to emerge from the analysis of lecturer responses to the survey questions in my study is that peer reviews had been effective 'at the level of epistemology', Frielick's indicator of academic development 'success'. All the lecturers who participated in the survey had changed in their understanding of their roles and responsibilities with regard to their teaching, and as a result had changed their 


\section{THE SCHOLARSHIP OF TEACHING AND LEARNING IN HIGHER EDUCATION}

teaching practice to being more student focused, for example by regularly including student problem-solving activities in class. Of the three lecturers who only moved from category $A$ to $B$, two were very young members of staff who continued to work with the STLC subsequent to the survey. The third was a lecturer who was deeply reluctant to engage and who had difficulty acceding that student participation was an important part of teaching. It was only after student input using a "stop/start/continue what you are doing" evaluation, where all the students indicated that he should stop 'just talking at them' and start 'allowing them to try working out problems in class', that he reluctantly started offering a few opportunities for some class engagement.

Three of the lecturers in my study echoed a comment by the lecturer holding the most complex view of teaching (category E) in the Ginns et al. (2008: 182) study, namely, in highlighting their "lack of an organising framework". One of the lecturers said, "I have enjoyed my teaching but have felt that I did not have a formal reference point against which to evaluate what I was doing." The second said, "[A]lthough I considered myself a relatively good lecturer, I did consider that there were a number of areas in which I could improve. However it was not clear to me what these were." The third lecturer, who went on to register for a Masters in Education, said, "[S]ubsequent to the peer review I became inspired to improve and professionalise my teaching and enrolled for a Masters in Education. With the understanding I have gained through two courses in pedagogy, I believe that my approach has become radically altered."

Ginns and colleagues note that the scholarly component of their Graduate Certificate in Educational Studies - namely, "raising participants' awareness of both the general and the discipline-based body of educational research" - had been "crucial in reflecting a more reflective, confident, evidence-based approach to teaching" (Ginns et al. 2008:182). The Graduate Certificate in Educational Studies (Higher Education) at the University of Sydney is a year-long, part-time programme which since 2001 has carried a financial reward for faculties depending on the number of staff who have completed it. In the absence of such a programme and the resources to support it in my context, evidence shows that peer reviews have succeeded in fostering a shift not only towards more student-focused teaching in the faculty, but also towards a more scholarly approach to teaching. The lecturer who went on to doing a Master's degree in Education said: "We get very limited training at the beginning of our careers and are expected to somehow know how to teach. For those of us with some kind of intuition, it is difficult; for those who have no clue how to teach, it becomes disempowering when you are constantly faced with negative feedback from students without knowing what you are doing wrong. The ALP (student appraisal system 'Assessment of Lecturer Practice') is very tough for many lecturers 
and I believe that it frequently results in lecturers feeling alienated from their students and the teaching process. I think peer reviews are an incredibly constructive approach to professionalising the teaching skills of lecturers."

In an institution where so many understand 'lecturing' as the transmission of content, the requirement for quality assurance has paved the way, through peer reviews, for an engagement with teaching and learning that extends beyond the original requirement for demonstration of competence, and beyond the insights offered by student evaluations through the ALPs.

\section{SIDE EFFECTS OF PEER REVIEWS: THE AFFECTIVE DIMENSION}

Lecturers who approach academic developers for an evaluation of their teaching often express their preference for having a review done by an education specialist rather than a colleague in their own discipline. The fact that I am not a specialist in their discipline creates a space that limits concerns about 'colleague competition'. For many lecturers, the competitive environment and the isolation of teaching means that they get little positive feedback about their teaching. Lecturers who are doing well 'collect' ALPs and enjoy the affirmation from them, but those who have had painful feedback may become even more isolated, with teaching growing less and less appealing.

The 'safe space' created during the course of a peer review contributes to one of the most important, yet initially unanticipated consequences, of the process which is the need to develop the confidence of lecturers. The academic developer has a unique opportunity to encourage good practice and give positive feedback. This translates into a sense of wellbeing and being valued with regard to the work they are doing, and this tends to deepen their engagement with their teaching. I have found that the 'hamburger approach' works very well in developing the trust that is a precondition to co-operative interaction and the development of a scholarly approach to teaching and learning; the hamburger filling represents constructive critique and suggestions for changes in practice, but this is preceded and followed by encouragement about what the lecturer is doing well.

Peer reviews serve to promote the work of the STLC as once contact has been established, lecturers lose their anxieties related to approaching academic developers for assistance. Their common room talk about their experiences encourages others to seek assistance as well. It is clear that having someone who affirms you and encourages you, who is an empathetic listener and with whom you can share some of the challenges and difficulties associated with teaching, and then help you deepen your practice, can be a life transforming experience. Sadly this is often lacking in a 


\section{THE SCHOLARSHIP OF TEACHING AND LEARNING IN HIGHER EDUCATION}

competitive university environment. Some of the comments given to questions 3 and 4 of the survey highlighted the unique opportunity afforded by peer reviews to build confidence, for example:

When Prof $X$ advised me to contact the Science Teaching and Learning Centre I was at first very concerned and scared. But it was such a useful and pleasant experience and l've learnt a lot and grown in confidence.

and,

Although I was a little nervous at first, it became clear that what I thought were 'trade secrets' by the lecturers with high ALPs were learned techniques that I could implement. I now think this is not only a process that should be engaged in for promotion's sake or for probation, but throughout the teaching experience because it provides opportunities for growth and affirmation. I am certainly more confident as a result of the process, particularly as a staff member who is more research than teaching active.

The approach to peer reviews as described here is very different to the approach where an evaluator attends only one lecture (which may even be unannounced) and constructs a summative report on teaching competence based only on that lecture. We all know how difficult it is to change how we do things, and few of us enjoy being criticised. Thus the approach to peer reviews in the faculty is to develop relationship, then engage lecturers at the level of epistemology and shift their understanding regarding what it means to be a good lecturer, rather than serve an evaluative rubber stamping role.

\section{CONCLUSION}

Globalisation and the massification of tertiary education have led to the need for accountability in terms of teaching quality. As one form of quality assurance, peer reviews of teaching serve not only an accountability function, but more importantly, as part of academic development, they can promote the development of scholarly teaching and lead to transformation in lecturers' understanding and practice in the teaching/learning environment. They offer the opportunity to build confidence and capacity and shift universities from institutions that exist to provide instruction to institutions that exist to produce learning (Barr \& Tagg 1995).

This chapter has reflected on the multiple levels of reward that can be associated with peer reviews: for the students who benefit from improved teaching; for the lecturers who develop in their capacity to teach well (and who may then be promoted or given tenure); and for the academic developer in knowing they have facilitated change that can impact on the quality of the learning experience. 
The chapter has also traced the trajectory of my own journey in academic development. My work with peer reviews rested initially on my own intuition on what could support lecturers in becoming better teachers. My standing and acceptance depended largely on my perceived attributes of academic qualifications in science and in education, as well as teaching experience in higher education. Consideration of the plight of the lecturers consulting me, or sent to me, led me to develop my practice with empathy and to reflect on its effects. While developing the necessary insights to assist them in bettering their practice, I was introduced to the field of SoTL work, first through acquiring and studying relevant literature and then enquiring into the results of my own practice as an academic developer. Now I am engaged in dissemination, for example through conference presentations and writing this chapter for this book.

\section{REFERENCES}

Aikenhead G. 1996. Science education: Border crossing into the subculture of science. Studies in Science Education, 27:1-52.

Anderson LW \& Krathwohl DR (eds.). 2001. A taxonomy for learning, teaching, and asssessing: A revision of Bloom's Taxonomy of Educational Objectives. New York: Longman.

Barr RB \& Tagg J. 1995. From teaching to learning - a new paradigm for undergraduate education. Change, 27(6): 12-25.

Bell M. 2001. Supported reflective practice: a programme of peer observation and feedback for academic teaching development. International Journal for Academic Development, 6(1):29-39.

Biggs J. 2003. Teaching for quality learning at university. Second edition. Buckingham: Open University Press/Society for Research into Higher Education.

Birman BF, Desimone L, Porter AC \& Garet MS. 2000. Designing professional development that works. Educational Leadership, 57(8):28-33.

Boughey C. 2013. The significance of structure, culture and agency in supporting and developing student learning at South African universities. In: R Dunpath \& R Vithal (eds.). Access and success in higher education. Cape Town: Pearson Educational. 61-87.

Boyle B, While D \& Boyle T. 2004. A longitudinal study of teacher change: What makes professional development effective? Curriculum Journal, 15(1):45-68.

Frielick S. 2004. The zone of academic development: an ecological approach to learning and teaching in higher education. Unpublished PhD thesis. Johannesburg: University of the Witwatersrand.

Frielick S \& McLachlan-Smith C. 1999. The value (added?) of academic development. HERDSA Annual International Conference. University of Melbourne, Melbourne, Australia. 12-15 July.

Ginns P, Kitay J \& Prosser M. 2008. Developing conceptions of teaching and the scholarship of teaching through a Graduate Certificate in Higher Education. International Journal for Academic Development, 13(3):175-185. 


\section{THE SCHOLARSHIP OF TEACHING AND LEARNING IN HIGHER EDUCATION}

Gosling D. 2009. Academic development identity and positionality. SRHE Academic Development Network paper. London: SRHE.

Green D \& Little D. 2013. Academic development on the margins. Studies in Higher Education, 38:523-537.

Lave J \& Wenger E. 1991. Situated learning: Legitimate peripheral participation. Cambridge, UK: Cambridge University Press.

Lindberg-Sand $\AA$ \& Sonesson A. 2008. Compulsory higher education ateacher training in Sweden: Development of a national standards framework based on the scholarship of teaching and learning. Tertiary Education and Management, 14(2):123-139.

Linder KE \& Felten P. 2015. Understanding the work of academic development. International Journal for Academic Development, 20(1): 1-3. doi:10.1080/1360144X.2014.998875

Marton F \& Säliö R. 1976. On qualitative differences in learning - I: Outcome and process. British Journal of Educational Psychology, 46:4-11.

Prebble T, Hargreaves H, Leach L, Naidoo K, Suddaby G \& Zepke N. 2005. Impact of student support services and academic development programmes on student outcomes in undergraduate tertiary study: A synthesis of the research. http://educationcounts.edcentre. govt.nz/publications/tertiary/impact-student.html [Accessed 6 December 2015].

Prosser M \& Trigwell K. 2001. Understanding learning and teaching: The experience in higher education. Buckingham: Open University Press/Society for Research in Higher Education.

Ramsden P. 1992. Learning to teach in higher education. London: Routledge.

Shulman L. 1986. Those who understand: Knowledge growth in teaching. Educational Researcher, 15(2):4-14.

Skelton A. 2007. Democratising excellence. Academy Exchange, 7:17-19.

Sunal DW, Hodges J, Sunal CS, Whitaker KW, Freeman LM, Edwards L \& Odell M. 2001. Teaching science in higher education: Faculty professional development and barriers to change. School Science and Mathematics, 101 (5):246-257. 